\title{
PENANGANAN MASALAH PEKERJA ANAK MELALUI \\ PEMBERDAYAAN ORGANISASI LOKAL "FORUM PEDULI ANAK" DI \\ KELURAHAN CIBEUREUM KOTA CIMAHI
}

\author{
Oleh: \\ Nada Kusuma ${ }^{1}$; Santoso Tri Raharjo ${ }^{2}$ \\ 1. Mahasiswa Program Magister Kesejahteraan Sosial FISIP Universitas Padjadjaran \\ 2. Staf Pengajar pada Departemen Kesejahteraan Sosial FISIP Universitas Padjadjaran \\ Email : \\ nadatamrin@gmail.com; santoso.tri.raharjo@unpad.ac.id
}

\begin{abstract}
This study aims to understand the process of empowerment of the FPA agencies in addressing the issue of child labor in Sub Cibeureum. The method used is a qualitative research method through descriptive research. Sources of primary data in this study are participants comprising officials FPA and child labor. while secondary data sources consist of documents FPA activity, some community leaders and some parents of child labor. Data collected through documentary studies, in-depth interviews, focus groups and participant observation. Collected data checked for validity through the extension of participation, persistence observation, trianguasi, checking the adequacy of their colleagues and references. Data which has proven its validity and then tested kualitatif.Hasil showed that the cause of child labor in Sub Cibeureum caused, among other things: poverty experienced by parents, their culture and tradition that sees the child to do the work as a form of devotion to the parents, and the availability of easy job accessible without the need for specific requirements. Child labor underpinning the establishment of the institution FPA by the community leaders. FPA institutions intended to address problems faced by child labor. In the implementation of the FPA agencies remains a bottleneck, caused by the lack of competence of the management in conducting the study groups and the lack of ability to access resources. These conditions give rise to the need to empower these institutions. Empowerment of FPA agencies conducted through reorganization and restructuring management. FPA successful empowerment activities to improve the ability of these institutions, so aim to conduct the study groups for working children can be reached.
\end{abstract}

Keywords: Child Labour, Empowerment, Child Care Forum

Kajian ini bertujuan untuk memahami proses pemberdayaan terhadap lembaga FPA dalam menangani masalah pekerja anak di Kelurahan Cibeureum. Metode yang digunakan adalah metode penelitian kualitatif melalui jenis penelitian deskriptif. Sumber data primer dalam penelitian ini merupakan partisipan yang terdiri dari para pengurus FPA dan pekerja anak. sedangkan sumber data sekunder terdiri dari dokumen kegiatan FPA, beberapa tokoh masyarakat dan beberapa orang tua dari pekerja anak. Pengumpulan data dilakukan melalui studi dokumentasi, wawancara mendalam, diskusi kelompok terfokus dan observasi partisipatif. Data yang terkumpul selanjutnya dicek keabsahannya melalui perpanjangan keikutsertaan, ketekunan pengamatan, trianguasi, pengecekan sejawat dan kecukupan referensi. Data yang telah teruji keabsahannya kemudian diuji secara kualitatif.

Hasil penelitian menunjukkan bahwa penyebab pekerja anak di Kelurahan Cibeureum disebabkan antara lain : kemiskinan yang dialami orangtua, adanya budaya dan tradisi yang memandang anak wajib melakukan pekerjaan sebagai bentuk pengabdian kepada orangtua, dan 
tersedianya pekerjaan yang mudah diakses tanpa membutuhkan persyaratan tertentu. Adanya pekerja anak ini mendasari dibentuknya lembaga FPA oleh para tokoh masyarakat.

Lembaga FPA dimaksudkan untuk menangani masalah yang dihadapi pekerja anak. Dalam pelaksanaannya lembaga FPA masih mengalami hambatan, yang disebabkan oleh kurangnya kompetensi pengurus dalam menyelenggarakan kegiatan kelompok belajar dan kurangnya kemampuan dalam mengakses sumber. Kondisi ini menimbulkan adanya kebutuhan untuk memberdayakan lembaga tersebut.

Pemberdayaan terhadap lembaga FPA dilakukan melalui reorganisasi dan restrukturisasi kepengurusan. Kegiatan pemberdayaan terhadap FPA berhasil meningkatkan kemampuan lembaga tersebut, sehingga tujuannya untuk melaksanakan kegiatan kelompok belajar bagi pekerja anak dapat tercapai.

Kata Kunci : Pekerja Anak, Pemberdayaan, Forum Peduli Anak

\section{PENDAHULUAN}

\section{Esensi community based development} memposisikan masyarakat sebagai subyek pembangunan, sehingga mereka lebih bertanggungjawab untuk mendukung, memelihara, dan meningkatkan hasil-hasil pembangunan secara berkesinambungan untuk kemaslahatan mereka bersama.

Sebagai bagian dari masyarakat bangsa, anak juga memiliki hak yang berguna dalam menjamin pertumbuhan dan perkembangannya. Pengakuan terhadap hak anak secara internasional dilakukan oleh Perserikatan Bangsa-bangsa melalui suatu konvensi pada tahun 1989. Prinsip-prinsip yang dianut dalam Konvensi Hak Anak adalah : Non Diskriminasi (Pasal 2). Semua hak anak yang diakui dan terkandung dalam KHA harus diberlakukan kepada setiap anak tanpa pembedaan apapun. Kepentingan terbaik untuk anak (Pasal 3). Semua tindakan yang menyangkut anak, pertimbangan utamanya adalah apa yang terbaik untuk anak. Kelangsungan hidup dan perkembangan anak
(Pasal 6). Hak hidup yang melekat pada diri setiap anak harus diakui atas kelangsungan hidup dan perkembangannya harus dijamin. Penghargaan terhadap pendapat anak (Pasal 12). Pendapat anak terutama yang menyangkut hal-hal yang dapat mempengaruhi kehidupannya, perlu diperhatikan dalam setiap pengambilan keputusan.

Konvensi Hak Anak tersebut diratifikasi oleh pemerintah Indonesia dalam Keppres No. 36 tahun 1990. Dalam Keppres tersebut dinyatakan bahwa anak memiliki hak-hak antara lain: hak untuk hidup layak, hak untuk berkembang, hak untuk dilindungi, hak untuk berperan serta, hak untuk menolak menjadi pekerja anak, dan hak untuk memperoleh pendidikan. Keppres ini kemudian menjadi salah satu dasar dari Undang-undang Nomor 23 tahun 2002 tentang Perlindungan Anak, seperti dijabarkan mulai dari pasa 4 sampai dengan pasal 18.

Dubowitz (2000:11) menyebutkan bahwa kebutuhan dasar anak meliputi : makanan yang memadai, pakaian, perumahan, perawatan 
kesehatan, pendidikan, pengawasan, perlindungan dari lingkungan yang berbahaya, perawat asuhan, kasih sayang, dukungan, dan cinta. Sedangkan Hurlock (1993:107), menyampaikan kebutuhan anak pada umumnya sebagai berikut : Kebutuhan fisik, Kebutuhan Emosional, Kebutuhan Intelektual Dengan melibatkan masyarakat dalam proses perencanaan dan pelaksanaan pembangunan dapat meningkatkan self-reliance yang dibutuhkan demi akselerasi program -program pembangunan (Bryant C. \& White, L. G., 1987).

Pemberdayaan pada lembaga Forum Peduli Anak (FPA) dilakukan untuk meningkatkan keberdayaan pada dimensi interpersonal dan politik. Hal ini disebabkan pada kedua dimensi itu lembaga Forum Peduli Anak (FPA) kurang berdaya, sehingga tujuannya belum dapat dicapai. Peningkatan keberdayaan dimensi interpersonal dan politik dari lembaga FPA setelah melalui proses pemberdayaan, dapat membantu lembaga tersebut untuk mencapai tujuannya yaitu menyelenggarakan kegiatan kelompok belajar bagi pekerja anak.

Pekerja anak merupakan salah satu fenomena permasalahan sosial yang dialami oleh anak. Fenomena ini awalnya kurang dianggap sebagai suatu permasalahan sosial karena terkait dengan budaya di beberapa tempat tertentu bahwa melibatkan anak dalam pekerjaan merupakan pembelajaran untuk memberikan bekal ketrampilan yang berguna bagi masa depan anak. Dengan tidak bermaksud untuk masuk dalam perdebatan tersebut, tinjauan konseptual dan teoritis ini akan menyoroti penyebab dan akibat dari pekerja anak, keterkaitan beberapa teori dalam memahami penyebab pekerja anak, dan akhirnya mengulas penanganan masalah pekerja anak.

Permasalahan yang dihadapi oleh para pekerja anak di Kelurahan Cibeureum bukan hanya rendahnya tingkat pendidikan yang disebabkan oleh putus sekolah, tetapi juga beberapa masalah lain yang dapat berdampak pada proses tumbuh kembang anak. Para pekerja anak ini juga rentan mengalami eksploitasi secara ekonomi dari keluarga mereka, dan beberapa bentuk perlakuan kasar di tempat mereka bekerja. Perlakuan kasar tersebut biasanya mereka terima dari rekan kerja yang lebih dewasa, sebagai bentuk dari adanya persaingan dalam melakukan pekerjaannya.

Kebijakan internasional dalam penanganan pekerja anak adalah dengan memberikan batasan usia pada anak untuk boleh mengerjakan jenis pekerjaan tertentu. Selain itu juga melarang anak-anak untuk bekerja pada sektor-sektor yang berbahaya atau jenis pekerjaan yang terburuk bagi anak. Sebagai jalan keluarnya, setiap negara yang meratifikasi aturan tersebut diwajibkan untuk menjamin setiap anak memperoleh kebutuhannya. Berbagai program pemerintah untuk menjamin agar setiap anak dapat tetap bersekolah dan tidak menjadi pekerja anak, 
tidak serta merta dapat membuat para pekerja anak di Kelurahan Cibeureum untuk kembali bersekolah. Anak-anak ini menyatakan bahwa mereka dan orangtuanya tetap tidak mampu membayar biaya sekolah yang masih mahal. Mereka masih memilih untuk tetap bekerja karena dapat menghasilkan uang. Anak-anak ini bekerja pada lingkungan kerja yang tidak sehat karena penuh dengan polusi, dan cenderung berbahaya karena resiko kecelakaan lalu-lintas yang cukup tinggi. Selain resiko fisik yang mungkin dialami oleh anak, mereka juga masih harus menanggung resiko rendahnya pengetahuan dan terbatasnya keterampilan sebagai akibat dari rendahnya tingkat pendidikan.

Istilah pekerja anak merupakan suatu istilah yang seringkali menimbulkan perdebatan, meskipun sama-sama digunakan untuk menggantikan istilah buruh anak. Departemen Tenaga Kerja dan Transmigrasi menggunakan istilah anak-anak yang terpaksa bekerja. Biro Pusat Statistik menggunakan istilah anak-anak yang aktif secara ekonomi. Namun demikian definisi Pekerja Anak yang dapat diterima secara umum adalah definisi yang disampaikan oleh ILO / IPEC. Menurut ILO / IPEC pekerja anak adalah anak yang bekerja pada semua jenis pekerjaan yang membahayakan atau mengganggu fisik, mental, intelektual dan moral.

Kondisi yang dialami oleh pekerja anak ini menarik perhatian para tokoh masyarakat setempat. Kondisi organisasi lokal Forum
Peduli Anak (FPA), yang beranggotakan para tokoh masyarakat yang memiliki kepedulian terhadap nasib dan masa depan anak di Kelurahan Cibeureum. Tujuan dibentuknya organisasi lokal ini adalah untuk menjamin terpenuhinya kebutuhan anak terutama kebutuhan pendidikan, pemanfaatan waktu luang yang positif untuk menunjang perkembangannya, dan melindungi anak dari perlakuan salah dan diskriminatif.

Kondisi ini menunjukkan adanya dukungan dari masyarakat terhadap rencana kegiatan. Hal ini setidaknya dapat dilihat dengan adanya antusiasme anak untuk mengikuti kegiatan kelompok belajar. Namun demikian tergambar juga adanya kendala yang dihadapi oleh Forum Peduli Anak dalam pelaksanaan kegiatannya. Kendala tersebut apabila tidak segera diatasi akan berdampak kontra produktif terhadap pencapaian tujuan forum itu sendiri. Hal inilah yang kemudian menarik perhatian peneliti untuk memahami secara lebih mendalam tentang kegiatan Organisasi Lokal Forum Peduli Anak. Tujuan penelitian ini menggambarkan penanganan pekerja anak melalui organisasi lokal Forum Peduli Anak di Kelurahan Cibeureum Kecamatan Cimahi Selatan Kota Cimahi

\section{TINJAUAN PUSTAKA}

\section{Pengertian Anak}

Anak merupakan bagian dari rentang kehidupan manusia yang berbeda dengan masa 
dewasa. Penetapan tentang usia anak disesuaikan dengan kepentingan masingmasing pihak yang mendefinisikannya.

Pembatasan usia anak yang jelas membedakannya dengan usia dewasa seperti disampaikan dalam Undang-Undang No. 23 tahun 2002 tentang Perlindungan Anak. Undang-undang tersebut merupakan ratifikasi dari Konvensi Hak Anak, yang menyatakan bahwa : "Anak adalah setiap orang yang belum berusia 18 (delapan belas) tahun termasuk anak yang masih dalam kandungan”. Batasan usia anak menurut UU No. 23/2002 ini merupakan penyempurnaan dari batasan yang diatur dalam UU No. 4 tahun 1979 tentang Kesejahteraan Anak. Undang-undang tersebut mendefinisikan anak sebagai seseorang yang belum berusia 21 tahun dan belum menikah.

\section{Hak dan Kewajiban Anak}

Sebagai bagian dari masyarakat bangsa, anak juga memiliki hak yang berguna dalam menjamin pertumbuhan dan perkembangannya. Pengakuan terhadap hak anak secara internasional dilakukan oleh Perserikatan Bangsa-bangsa melalui suatu konvensi pada tahun 1989. Prinsip-prinsip yang dianut dalam Konvensi Hak Anak adalah

a. Non Diskriminasi (Pasal 2). Semua hak anak yang diakui dan terkandung dalam KHA harus diberlakukan kepada setiap anak tanpa pembedaan apapun. b. Kepentingan terbaik untuk anak (Pasal 3). Semua tindakan yang menyangkut anak, pertimbangan utamanya adalah apa yang terbaik untuk anak.

c. Kelangsungan hidup dan perkembangan anak (Pasal 6). Hak hidup yang melekat pada diri setiap anak harus diakui atas kelangsungan hidup dan perkembangannya harus dijamin.

d. Penghargaan terhadap pendapat anak (Pasal 12). Pendapat anak terutama yang menyangkut hal-hal yang dapat mempengaruhi kehidupannya, perlu diperhatikan dalam setiap pengambilan keputusan.

Konvensi Hak Anak tersebut diratifikasi oleh pemerintah Indonesia dalam Keppres No. 36 tahun 1990. Dalam Keppres tersebut dinyatakan bahwa anak memiliki hak-hak antara lain: hak untuk hidup layak, hak untuk berkembang, hak untuk dilindungi, hak untuk berperan serta, hak untuk menolak menjadi pekerja anak, dan hak untuk memperoleh pendidikan. Keppres ini kemudian menjadi salah satu dasar dari Undang-undang Nomor 23 tahun 2002 tentang Perlindungan Anak, seperti dijabarkan mulai dari pasa 4 sampai dengan pasal 18.

Selain itu menurut UU No. 23/2002 pasal 19, setiap anak memiliki kewajiban untuk :

menghormati orangtua, wali dan guru, mencintai keluarga, masyarakat dan menyayangi teman, mencintai tanah air, bangsa dan negara, menunaikan ibadah sesuai dengan ajaran agamanya, dan melaksanakan etika dan akhlak yang mulia. 


\section{Tugas Perkembangan Anak}

Tugas perkembangan pada dasarnya merupakan suatu tugas yang muncul pada periode tertentu dalam rentang kehidupan individu, yang apabila tugas itu dapat berhasil dituntaskan akan membawa kebahagiaan dan kesuksesan dalam menuntaskan tugas berikutnya; sementara apabila gagal, maka akan menyebabkan ketidakbahagiaan pada diri individu yang bersangkutan, menimbulkan penolakan masyarakat, dan kesulitan-kesulitan dalam menuntaskan tugas-tugas berikutnya (Havighurst, 1961; dalam Yusuf, 2004:65)

Berdasarkan pandangan tersebut, maka tugas perkembangan anak dapat dikelompokkan sebagai berikut :

a. Tugas perkembangan pada usia bayi dan kanak-kanak (0-6 tahun), meliputi : belajar berjalan; belajar memakan makanan padat; belajar berbicara; belajar buang air kecil dan air besar; belajar mengenal perbedaan jenis kelamin; mencapai kestabilan jasmaniah fisiologis; membentuk konsep-konsep sederhana kenyataan sosial dan alam; belajar mengadakan hubungan emosional dengan orangtua, saudara dan orang lain; belajar mengadakan hubungan baik dan buruk. (Yusuf, 2004: 66-68)

b. Tugas perkembagan pada masa sekolah (6-12 tahun) meliputi : belajar memperoleh keterampilan fisik untuk melakukan permainan; belajar membentuk sikap yang sehat terhadap dirinya sendiri sebagai makhluk biologis; belajar bergaul dengan teman-teman sebaya; belajar memainkan peranan sesuai dengan jenis kelaminnya; belajar keterampilan dasar dalam membaca, menulis dan berhitung; belajar mengembangkan konsep sehari-hari; mengembangkan kata hati; belajar memperoleh kebebasan yang bersifat pribadi; mengembangkan sikap yang positif terhadap kelompok sosial dan lembaga-lembaga. (Yusuf, 2004: 69-71)

c. Tugas perkembangan pada masa remaja menurut William Kay meliputi: menerima fisiknya sendiri berikut keragaman kualitasnya; mencapai kemandirian emosional dari orangtua atau figur-figur yang mempunyai otoritas; mengembangkan ketrampilan komunikasi interpersonal dan belajar bergaul dengan teman sebaya atau orang lain, baik secara individual maupun kelompok; menemukan manusia model yang dijadikan identitasnya; menerima dirinya sendiri dan memiliki kepercayaan terhadap kemampuannya sendiri; memperkuat self-control (kemampuan mengendalikan diri) atas dasar skala nilai, prinsip-prinsip atau falsafah hidup (weltanschauung); mampu meninggalkan reaksi dan penyesuaian diri (sikap/perilaku) kekanak-kanakan. (Yusuf, 2004: 72-73).

Menurut Havighurst (1961) dalam Yusuf (2004: 74-93) tugas perkembangan pada masa remaja meliputi : mencapai hubungan yang lebih matang dengan teman sebaya; mencapai peran sosial sebagai pria atau wanita; menerima keadaan fisik dan menggunakannya secara efektif; mencapai kemandirian emosional dari orangtua dan orang dewasa lainnya; mencapai jaminan kemandirian ekonomi; memilih dan mempersiapkan karier (pekerjaan); mempersiapkan pernikahan dan 
hidup berkeluarga; mengembangkan keterampilan intelektual dan konsep-konsep yang diperlukan bagi warga negara; mencapai tingkah laku yang bertanggung jawab secara sosial; memperoleh seperangkat nilai dan sistem etika sebagai petunjuk/pembimbing dalam bertingkah laku; beriman dan bertaqwa kepada Tuhan Yang Maha Esa.

\section{Kebutuhan Anak}

Setiap manusia dalam menjalani kehidupannya tidak terlepas dari beragam kebutuhan baik fisik, mental, emosional yang semuanya itu merupakan alat dan sarana untuk mencapai keberfungsiannya secara utuh. Prasyarat utama agar anak dapat tumbuh dan berkembang secara normal adalah terpenuhinya kebutuhan dasar anak yang meliputi kebutuhan psikologis, kasih sayang, pendidikan, pemeliharaan kesehatan, perlindungan terhadap segala diskriminasi dan perlakuan salah, serta kesempatan untuk menyuarakan pendapatnya dalam berbagai keputusan yang menyangkut nasib dirinya.

Dubowitz (2000:11) menyebutkan bahwa kebutuhan dasar anak meliputi : makanan yang memadai, pakaian, perumahan, perawatan kesehatan, pendidikan, pengawasan, perlindungan dari lingkungan yang berbahaya, perawat asuhan, kasih sayang, dukungan, dan cinta. Sedangkan Hurlock (1993:107), menyampaikan kebutuhan anak pada umumnya sebagai berikut :

\section{Kebutuhan fisik}

Dalam hal ini seorang anak memerlukan perawatan untuk kesehatan, kebutuhan akan pakaian, pangan, perumahan dan lain-lain.

\section{Kebutuhan emosional}

Anak memerlukan kasih sayang yang cukup untuk mendukung kestabilan emosi, perkembangan kepribadiannya serta merangsang kreatifitas anak.

\section{Kebutuhan intelektual}

Anak membutuhkan pengetahuan untuk mengembangkan pengetahuan dan intelektualnya, maka pengetahuan tentang cara bergaul dengan orang lain akan mudah dipahami anak.

Kebutuhan anak pada dasarnya tidak dapat disama ratakan, karena mengikuti pada tahap perkembangan anak. Pemenuhan kebutuhan anak akan berdampak pada pertumbuhan fisik, perkembangan intelektual, mental dan sosial. Kegagalan dalam pemenuhan kebutuhan anak akan membawa dampak yang negatif pada diri anak pada fase perkembangan selanjutnya. Anak yang menemui kegagalan dalam pemenuhan kebutuhannya akan mudah mengalami kegagalan dalam penyesuaian diri.

Kebutuhan anak secara spesifik akan berbedabeda sesuai dengan tahapan perkembangan anak. Papalia (2001: 14-16) membagi tahapan perkembangan dalam delapan tahapan, yang secara umum diterima oleh masyarakat industri barat. Delapan tahapan tersebut 
meliputi : masa konsepsi (masa pembuahan sampai dilahirkan sebagai bayi), masa bayi, kanak-kanak awal, kanak-kanak akhir, remaja, dewasa awal, dewasa pertengahan, dan dewasa akhir atau lanjut usia.

Pada masa bayi, kebutuhan anak lebih ditekankan pada pemenuhan kebutuhan dasar seperti makanan, pakaian, tempat tinggal, perhatian dan kasih sayang terutama dari orangtua atau pengasuhnya. Pada masa kanakkanak awal, anak lebih banyak membutuhkan perhatian sehingga mampu mengembangkan kontrol dirinya. Pada masa kanak-kanak akhir, seorang anak lebih banyak membutuhkan bergaul dengan teman sebayanya. Dengan demikian anak dapat mulai mempelajari perilaku yang sesuai dengan lingkungannya.

Pada masa remaja, anak mulai mengembangkan kosep dirinya untuk mencari identitas diri. Dalam masa ini anak tidak hanya membutuhkan pendidikan yang memadai, tetapi juga kasih sayang dan perhatian dari orangtua agar anak tidak salah dalam mengembangkan konsep dirinya. Disamping itu dukungan emosional dari peer group juga sangat dibutuhkan. Hal ini disebabkan oleh adanya kecenderungan kedekatan remaja dengan peer group-nya dari pada dengan orangtuanya sendiri.

\section{Permasalahan Anak}

Berbagai permasalahan yang seringkali dihadapi anak, biasanya muncul sebagai hasil interaksi antara anak dengan orang yang lebih dewasa dalam lingkungan sosialnya (Hill dan Tisdall: 1997:16). Permasalahan yang dihadapi oleh anak dapat dikelompokkan dalam dua kelompok besar yaitu child neglect dan child abuse, kedua permasalahan tersebut dapat dikatakan sebagai child maltreatment (perlakuan salah terhadap anak). Perlakuan salah terhadap anak dapat dikategorikan dalam empat jenis yaitu, perlakuan salah secara fisik (physical abuse), perlakuan salah secara emosional (emotional abuse / psychological maltreatment), penelantaran anak (child neglect), dan perlakuan salah secara seksual (sexual abuse) (Dubois, 2005:373).

Physical abuse didefinisikan sebagai sebuah tindakan yang berakibat pada luka-luka secara fisik atau yang bersiko dapat menyebabkan luka (Dubowitz, 2000:15). Sedangkan Zastrow (2004) dan Dubois (2005) mendefinisikannya sebagai luka-luka yang bukan berasal dari kecelakaan melainkan sebagai suatu akibat dari tindakan membahayakan yang biasanya dilakukan oleh orang yang lebih dewasa (orangtua, teman yang lebih dewasa, pengasuh, saudara). Tindakan tersebut dapat berupa pukulan, tendangan, dibakar, atau gigitan.

Emotional abuse adalah perilaku orangtua atau pengasuh yang secara sadar dilakukan sehingga merugikan anak secara emosional. Zastrow (2004:175) menyebutkan bahwa emotional abuse and emotional neglect merupakan dua tindakan yang termasuk dalam 
emotional maltreatment. Perilaku yang dapat dikategorikan sebagai emotional maltreatment meliput: penolakan, pengisolasian, teror atau tindakan yang menimbulkan kengerian, pengabaian, dan penyalahgunaan.

Child neglect merupakan tindakan penelantaran yang dilakukan dalam bentuk tidak memenuhi kebutuhan dasar anak untuk mencapai kesehatan dan keselamatan. Lebih lanjut Dubois (2005:373) menjelaskan bahwa yang termasuk dalam penelantaran anak meliputi penelantaran secara fisik (pengabaian terhadap pelayanan kesehatan), penelantaran pendidikan (pengabaian terhadap anak sehingga tidak dapat bersekolah), dan penelantaran secara emosional (pengabaian terhadap pemenuhan kebutuhan kasih sayang).

Sexual abuse seringkali berupa tindakan seksual terhadap seorang anak dimana anak tersebut tidak menghendakinya, biasanya dilakukan dengan melalui paksaan menggunakan kekuatan, ancaman dengan tindakan kekerasan. Sexual abuse dapat berupa sodomi, porngrafi anak, berbagai bentuk kegiatan seksual yang pada dasarnya belum dipahami oleh anak, merayu, dan persetubuhan baik dengan orang lain maupun dengan saudara sekandung (Zastrow 2004:177, Dubois 2005:373). Menurut Suharto (2005:161) beberapa permasalahan anak yang termasuk dalam kategoti perlakuan salah terhadap anak meliputi:
Anak yang mengalami pengabaian (child neglect) dan eksploitasi (child exploitation), Anak yang berada dalam kondisi darurat, Anak yang diperdagangkan (child traficking), Anak yang terlibat kriminalitas atau berkonflik dengan hukum, Anak yang terlibat dalam produksi dan perdagangan obat terlarang, termasuk anak korban penyalahgunaan NAPZA, Anak korban HIV/AIDS, Anak korban diskriminasi sosial.

Sejalan dengan beberapa pengertian tersebut, akhir-akhir ini mulai banyak dijumpai adanya fenomena anak-anak yang bekerja atau terpaksa bekerja. Anak-anak yang bekerja dipandang sebagai media pembelajaran kepada anak untuk mempersiapkan masa depanya. Dalam batasan ini bukanlah merupakan suatu masalah karena kebutuhan anak masih dapat terpenuhi. Anak masih dapat memperoleh pendidikan, kesempatan bermain dan bersosialisasi dengan teman sebayanya.

Adapun anak yang terpaksa bekerja atau bahkan mungkin dipekerjakan, merupakan bentuk eksploitasi terhadap anak. Dalam hal ini anak tidak dapat terpenuhi beberapa kebutuhannya antara lain kebutuhan kesempatan bermain, bersosialisasi dengan teman sebaya dan kebutuhan untuk memperoleh pendidikan. Dengan demikian anak tidak hanya menjadi korban eksploitasi tetapi juga mengalami penelantaran. 


\section{METODE PENELITIAN}

Penelitian ini menggunakan pendekatan penelitian kualitatif deskriptif. Penelitian kualitatif merupakan penelitian yang dilandasi oleh paradigma post-positifistik yang dilakukan untuk memperoleh penjelasan mengenai penyebab munculnya suatu fenomena dengan mengumpulkan data berupa kata-kata. Lokasi Penelitian Penelitian ini dilakukan di Kelurahan Cibeureum Kecamatan Cimahi Selatan Kota Cimahi. Pemilihan lokasi ini didasarkan pada pertimbangan bahwa di wilayah tersebut ditemukan adanya pekerja anak. Mereka bekerja sebagai kusir delman (dalam bahasa setempat disebut keretek), dan menjadi pedagang keliling.

Pengumpulan data dalam penelitian ini dilakukan melalui penggunaan teknik-teknik pengumpulan data sebagai berikut : Studi dokumentasi, dilakukan terhadap sumber data sekunder untuk mendapatkan informasi pelengkap mengenai permasalahan penelitian. Dokumen yang digunakan berasal dari laporan kegiatan dan dokumen-dokumen pendataan terhadap pekerja anak. Wawancara mendalam kepada informan.

\section{HASIL DAN PEMBAHASAN}

\section{Profil Pekerja Anak}

Fenomena pekerja anak akhir-akhir ini ramai menjadi bahan pembicaraan di masyarakat, karena kesadaran akan pentingnya posisi anak dalam kehidupan berbangsa dan bernegara. Pekerja anak yang ada di Kelurahan Cibeureum bekerja sebagai kusir delman (keretek) dan pedagang keliling. Delman merupakan salah satu alat transportasi tradisional yang masih banyak digunakan oleh warga Kelurahan Cibeureum. Meskipun belakangan ini sempat terjadi polemik berkaitan dengan polusi dari kotoran kuda yang dihasilkan, bekerja sebagai kusir delman masih menjadi pilihan yang cukup menjanjikan bagi sebagian masyarakat. Delman mulai beroperasi di wilayah Kelurahan Cibeureum pada dekade 19701980an. Pemanfaatan delman sebagai alat transportasi mencapai puncaknya pada tahun 1990an. Pada tahun tersebut anak-anak mulai ikut-ikutan menjadi 'kenek’ dari kusir delman. Kegiatan inilah yang mengawali keterlibatan anak dalam aktifitas sebagai kusir delman.

Gambaran mengenai karakteristik anak yang bekerja sebagai kusir delman di Kelurahan Cibeureum dapat diketahui dari beberapa aspek berikut ini: Usia Berdasarkan hasil observasi partisipatif dan wawancara mendalam dengan pekerja anak di tempat pangkalan delman, peneliti menemukan adanya 22 anak yang bekerja sebagai kusir. Mereka berusia antara 11 tahun sampai 17 tahun, dengan usia terbanyak adalah 14 tahun (8 orang anak). Mereka mulai menjadi kusir antara usia 7 tahun sampai 13 tahun, dengan usia terbanyak adalah 10 tahun (9 orang anak). Usia dimana seorang anak mulai melakukan 
aktifitas sebagai kusir cenderung berpengaruh terhadap tingkatan sekolah yang mereka tempuh. Anak-anak yang memulai kegiatannya sebagai kusir pada usia 8 tahun, memiliki kecenderungan untuk lebih cepat putus sekolah. Biasanya anak-anak ini pendidikan tertingginya hanyalah tamat SD. Pada anak yang memulai kegiatannya sebagai kusir pada usia diatas 8 tahun atau mendekati 10 tahun, kecenderungan putus sekolahnya agak lambat. Mereka bisa mencapai pendidikan tertingginya sampai dengan tamat SMP. Status pendidikan kusir anak terdiri dari masih sekolah dan putus sekolah. Mereka yang masih sekolah berjumlah 6 orang, dengan rincian 4 orang bersekolah di SD, 2 orang di SMP (kelas 2 dan 3). Mereka yang putus sekolah berjumlah 16 orang, dengan rincian 1 orang putus sekolah SMA, 1 orang putus sekolah SMP, 9 orang lulus SD dan 5 orang tidak tamat SD. Tingkat pendidikan tertinggi dari para kusir anak ini hanyalah lulus SMP. Meskipun ada yang berhasil melanjutkan ke jenjang SMA, namun akhirnya harus berhenti juga setelah memasuki semester kedua. Sedangkan rata-rata pendidikan kusir anak yang lainnya adalah tidak tamat SD dan tidak tamat SMP. Tingkat pendidikan para kusir anak selengkapnya dapat dilihat pada tabel 8 tentang karakteristik kusir anak. Status Dalam Keluarga Jumlah anggota keluarga yang dimiliki oleh para pekerja anak sangat bervariasi, mulai dari 2 bersaudara sampai dengan 10 bersaudara dalam satu keluarga.
Dari 22 orang anak yang menjadi kusir, 7 orang diantaranya memiliki 3 orang saudara dalam keluarga. Berdasarkan kedudukannya dalam keluarga, 8 dari 22 orang anak yang menjadi kusir adalah anak pertama dengan jenis kelamin laki-laki.

Informasi diatas menjelaskan bahwa pada anak pertama dan berjenis kelamin laki-laki, turut memegang peranan penting dalam perekonomian keluarga. Bekerja dan memperoleh uang bagi mereka menjadi hal yang lebih penting, dari pada bersekolah yang justru membutuhkan biaya besar. Bekerja bagi anak-anak ini tidak sekedar untuk mencari kesenangan, tetapi juga sebagai bentuk pengabdian mereka pada orangtua. Informasi ini peneliti peroleh pada saat menyaksikan seorang kusir anak yang menyerahkan penghasilannya kepada orangtua mereka.

\section{Pandangan Terhadap Pekerjaan Yang Dilakukan}

Anak-anak yang menjadi kusir memandang pekerjaan yang mereka lakukan sebagai aktifitas bermain yang mendatangkan uang. Hal ini memicu munculnya rasa senang pada anak terhadap aktifitasnya tersebut. Pandangan ini terutama dimiliki oleh anak-anak warga setempat. Berbeda dengan anak dari warga setempat, anak warga pendatang memandang pekerjaan yang mereka lakukan sebagai bentuk pengabdian anak terhadap orangtua. Pengabdian ini akan sangat terasa terutama 
pada anak pertama dengan kondisi orangtua yang sudah tidak mampu lagi bekerja, atau kondisi pekerjaan orangtua dengan penghasilan yang sangat kecil.

Perbedaan pandangan terhadap pekerjaan yang dilakukan ini mempengaruhi perilaku anak sehari-hari. Anak yang menganggap bekerja sebagai bentuk pengabdian, cenderung melakukan aktifitasnya dengan sangat serius dan mengatur penggunaan penghasilan dengan sangat baik. Sedangkan anak yang menganggap bekerja sebagai aktifitas bermain, menunjukkan kecenderungan yang sebaliknya. Delman yang digunakan oleh para pekerja anak ini status kepemilikannya sangat bervariasi. Dari 22 anak yang menjadi kusir, 8 orang mengoperasikan delman yang merupakan milik orangtua, yang kemudian dikelola oleh anak-anak mereka sebagai usaha menambah pendapatan keluarga. Ada pula delman yang disewa dari para juragan dengan sistim setoran. Mereka juga berjumlah 8 orang. Selain itu ada 6 orang anak yang merupakan "kusir tembak" dengan pembagian penghasilan berdasarkan sistim bagi hasi.

Para kusir anak yang bekerja di Kelurahan Cibeureum tidak hanya anak dari warga setempat, tetapi juga warga pendatang yang berasal dari Kelurahan Cigugur Tengah, Melong, Utama, Kabupaten Bandung, Garut dan Tasikmalaya. Tempat tinggal para kusir pendatang ini mengikuti para juragan yang memiliki delman, dengan sistem sewa.
Biasanya mereka disediakan tempat tinggal khusus yang letaknya berdekatan dengan kandang kuda (dalam istilah lokal tempat tinggal ini disebut kampus).

Jalur yang menjadi trayek delman ini meliputi jalan raya dengan kondisi jalan sebagian besar rusak, dengan panjang jalan maksimal kurang lebih $7 \mathrm{Km}$. Jalur ini melintasi kawasan industri dan beberapa kawasan pemukiman yang merupakan wilayah RW 15, 16, 17, 18, 27, 30 dan RW 08 Kelurahan Cigugur tengah. Kepemilikan delman paling banyak berasal dari warga RW. 16. Di wilayah ini pula paling mudah ditemukan anak-anak yang menjadi kusir, meskipun mereka tidak semuanya merupakan warga setempat.

Penggunaan waktu bekerja bagi para kusir delman anak tidak sama antara mereka yang masih sekolah dan yang sudah tidak bersekolah. Pekerja anak yang masih sekolah menggunakan waktu bekerja setelah pulang sekolah. Biasanya mulai dari jam 2 siang sampai jam 7 malam (5 jam dalam sehari). Anak-anak yang sudah tidak bersekolah menggunakan waktu bekerja relatif lebih panjang, mereka mulai bekerja dari jam 8 pagi sampai jam 8 malam (12 jam dalam sehari).

Permasalahan yang dihadapi oleh kusir delman adalah putus sekolah dan eksploitasi secara ekonomi. Adanya masalah putus sekolah yang dialami oleh para kusir anak disebabkan oleh beberapa faktor antara lain: ekonomi dan pengaruh lingkungan setempat yang kurang 
memberikan respon positif terhadap pendidikan bagi anak. Para pekerja anak ini sebenarnya masih memiliki minat atau keinginan untuk bersekolah, meskipun minat tersebut sangat kecil dan tidak sebesar motivasi mereka untuk mendapatkan uang dengan bekerja sebagai kusir. Pada hari dan jam sekolah anak-anak ini lebih banyak berada di pangkalan delman dari pada mengikuti kegiatan belajar di sekolah.

Masalah lain yang dirasakan oleh mereka adalah adanya kecenderungan anak mengalami eksploitasi secara ekonomi. Penghasilan yang mereka peroleh dari bekerja sepanjang hari hasilnya semua harus disetor kepada orang tuanya. Aktivitas bekerja yang dilakukan sangat menyita waktu (lihat tabel 6 dan 7 tentang pola pemanfaatan waktu), sehingga mereka kurang memiliki waktu untuk belajar dan bermain. Hal ini akan berdampak pada kurangnya minat untuk sekolah dan minat belajar. Kondisi kusir anak yang berada pada tahap perkembangan dimana anak seharusnya masih dalam tahap belajar dan bermain, tetapi waktu yang dimiliki harus digunakan untuk bekerja. Dengan banyaknya waktu yang digunakan untuk bekerja, membuat ketertarikan anak ke sekolah mulai berkurang. Anak mulai malas untuk pergi bersekolah dan lebih memilih bekerja menjadi kusir.

Perlakuan dan penerimaan lingkungan keluarga terhadap aktivitas pekerja anak tidak sama. Pada keluarga yang masih menginginkan anaknya sekolah menganggap pekerjaan yang dilakukan oleh anak merupakan kegiatan mengisi waktu luang dan mencari uang untuk keperluannya sendiri. Sementara pada keluarga yang kondisi ekonominya pas-pasan dan anak yang bekerja sebagai tulang punggung keluarga, maka hal itu merupakan bentuk tanggung jawab anak terhadap keluarganya.

Lingkungan tempat dimana anak melakukan aktivitas pekerjaannya, menganggap kusir anak merupakan saingan bagi mereka. Anggapan ini berakibat pada munculnya beberapa permasalahan yang dihadapi oleh kusir anak di tempat mereka bekerja. Kadangkadang para kusir anak ini menerima perlakuan kasar pada saat bersaing mencari penumpang.

\section{Pemanfaatan pelayanan Lembaga FPA}

Lembaga "Forum Peduli Anak" adalah kelompok yang terbentuk dari adanya aspirasi masyarakat untuk memberikan pelayanan terhadap pekerja anak dan anak putus sekolah di Kelurahan Cibeureum. Para kusir anak memperoleh informasi mengenai adanya lembaga FPA dari pamflet yang dipasang di tempat-tempat umum, dan adanya kegiatan sosialisasi dan motivasi yang dilakukan oleh peneliti.

Pelayanan yang diberikan oleh lembaga FPA berupa penyelenggaraan pendidikan non formal dalam bentuk kegiatan kelompok 
belajar. Sasaran utama kegiatan ini adalah pekerja anak, namun demikian dapat juga dimanfaatkan oleh anak putus sekolah. Kegiatan kelompok belajar dimulai dengan melakukan sosialisasi kepada sasaran kegiatan.

Pelayanan lembaga FPA belum dapat dimanfaatkan oleh para pekerja anak. Lembaga tersebut baru dapat melakukan sosialisasi kegiatan kepada 22 orang kusir anak. Sedangkan kegiatan kelompok belajar belum dapat dimanfaatkan karena kegiatannya belum berjalan.

Sosialisasi terhadap kusir anak dilakukan untuk memberikan informasi tentang rencana kegiatan kelompok belajar. Rencana tersebut disambut gembira oleh anak dan mereka menyatakan kesediaannya untuk mengikuti kegiatan. Anak-anak tersebut mengharapkan kegiatan kelompok belajar yang dilakukan tidak mengganggu aktifitas mereka dalam bekerja.

\section{Penanganan Masalah Pekerja Anak oleh}

\section{Lembaga "Forum Peduli Anak"}

Fenomena pekerja anak di Kelurahan Cibeureum merupakan permasalahan sosial yang muncul karena beberapa faktor. Rendahnya dukungan keluarga kepada anak untuk bersekolah, mudahnya anak memperoleh uang dengan menjadi kusir, pemberian penghargaan sebagai anak yang berbakti bagi anak yang membantu keluarga mencari nafkah, dan kurangnya motivasi anak untuk belajar, merupakan beberapa penyebab adanya pekerja anak di wilayah tersebut. Situasi tersebut menyebabkan tidak dapat terpenuhinya kebutuhan pendidikan bagi anak.

Penanganan masalah pekerja anak oleh lembaga FPA diutamakan untuk memenuhi kebutuhan pendidikan bagi anak. Rencana ini disesuaikan dengan kebijakan utama penanganan pekerja anak, yaitu mengembalikan para pekerja anak ke dunia pendidikan. Selain itu pilihan rencana didasarkan pada pertimbangan bahwa pendidikan merupakan salah satu bekal hidup terbaik bagi masa depan anak. Untuk memahami penanganan masalah pekerja anak yang sudah dilakukan oleh lembaga FPA, peneliti melakukan refleksi terhadap kegiatan yang mereka lakukan, sebagai berikut: Penanganan masalah pekerja anak yang sudah dilakukan oleh lembaga FPA meliputi : Sasaran penyuluhan adalah para orangtua yang memiliki pekerja anak dan anak putus sekolah, para juragan delman dan tokoh masyarakat. Penyuluhan ini bertujuan untuk mempengaruhi pola pikir masyarakat tentang pentingnya pendidikan bagi masa depan anak. Kegiatan penyuluhan dilakukan melalui tatap muka dan penyebarluasan pamflet. Penyuluhan melalui tatap muka dilakukan sebanyak 2 kali, dengan mengangkat materi tentang pekerja anak dan hak-hak anak. Metode yang digunakan adalah 
ceramah dan diskusi dengan membagikan makalah kepada peserta sebagai bahan diskusi.

Penyuluhan tentang hak-hak anak dan dampak bekerja bagi anak berhasil mempengaruhi pola pikir peserta tentang pekerja anak. Setelah mengikuti penyuluhan mereka memahami pentingnya pemenuhan hak-hak anak dan resiko yang akan ditanggung oleh pekerja anak pada masa dewasanya.

Akan tetapi kegiatan ini belum diikuti oleh para juragan delman dan seluruh orangtua yang memiliki pekerja anak, sehingga pemahaman tersebut hanya dimiliki oleh sebagian orang. Kondisi ini mendorong dilaksanakannya suatu bentuk penyuluhan yang lebih mudah menjangkau semua lapisan masyarakat, sehingga mereka memahami pentingnya pemenuhan hak anak dan resiko yang akan dialami pekerja anak pada masa dewasanya.

Penyebarluasan pamflet yang berisi tentang pekerja anak dan hak anak, dilakukan sebagai upaya penyebarluasan informasi untuk mempengaruhi opini masyarakat. Kegiatan ini merupakan pelengkap dari penyuluhan, karena lebih mudah menjangkau banyak pihak. Pemasangan pamflet dilakukan secara merata di beberapa RW dengan prioritas wilayah yang menjadi kantong pekerja anak dan anak putus sekolah. Pelaksanaan kegiatannya berkoordinasi dengan para Ketua RW dan RT. Hal ini dilakukan untuk menjamin ketepatan sasaran.
Kegiatan penyebarluasan pamflet ke wilayahwilayah kantong pekerja anak dan anak putus sekolah mendapat reaksi positif. Para pekerja anak dan anak putus sekolah merespon adanya pamflet tersebut dengan menghubungi Ketua RT setempat, dan menyatakan keinginannya untuk kembali bersekolah. Mereka bersedia mengikuti kegiatan kelompok belajar asalkan tidak memerlukan biaya yang cukup besar.

Kegiatan sosialisasi dan motivasi kepada para pekerja anak dilakukan melalui suatu acara "ngaliwet" (istilah lokal yang menunjukkan kegiatan masak dan makan bersama) pada malam hari. Pemilihan waktu ini dengan pertimbangan mereka sudah beristirahat dari aktifitas kerja. Pada kegiatan "ngaliwet" ini peneliti menyampaikan informasi tentang rencana dilakukannya kegiatan kelompok belajar, dan meminta tanggapan mereka tentang rencana tersebut. Disamping itu peneliti juga memotivasi mereka dengan menyampaikan kondisi mereka saat ini bila dikaitkan dengan harapan atau cita-cita masa depan mereka.

Sosialisasi kepada para pekerja anak disamping bertujuan untuk menyampaikan informasi tentang rencana kegiatan kelompok belajar, juga bertujuan untuk mengetahui minat mereka terhadap pendidikan. Dengan demikian dapat diperoleh umpan balik bagi FPA untuk merancang bentuk kegiatan belajar yang menarik bagi para calon warga belajar. Informasi tersebut juga peneliti manfaatkan untuk menentukan titik masuk dalam 
memotivasi mereka untuk bersedia kembali belajar ke bangku sekolah.

Kegiatan ini berhasil memperoleh informasi tentang minat anak untuk kembali bersekolah dan model pendidikan yang mereka inginkan. Meskipun tidak semua pekerja anak yang mengikuti kegiatan menyatakan bersedia kembali sekolah, namun hampir semua dari mereka menyatakan bersedia mengikuti kegiatan kelompok belajar asalkan tidak menghalangi pekerjaan mereka. Persyaratan tersebut disampaikan karena bekerja bagi mereka sangat penting. Kondisi keluarga yang kurang mampu yang menyebabkan keluarga tersebut tidak dapat memenuhi beberapa kebutuhan dasar anak, menjadi alasan utama mereka menjadi pekerja anak. Dengan demikian pelaksanaan kegiatan belajar yang mereka inginkan adalah pada saat mereka selesai bekerja.

Kegiatan yang sudah dilaksanakan tersebut kemudian dinilai keberhasilannya dalam mencapai tujuan. Selain itu juga dilihat partisipasi mereka dalam setiap kegiatan yang dilakukan. Berdasarkan penilaian tersebut diketahui bahwa kegiatan yang dilakukan dapat mencapai tujuan yang diinginkan. Akan tetapi dari aspek partisipasi para pengurus mengakui bahwa partisipasi mereka masih kurang. Mereka masih sangat tergantung pada peneliti untuk pelaksanaan kegiatan penyuluhan, demikian pula dengan pembuatan pamflet. Kondisi ini diakui oleh para pengurus sebagai suatu kelemahan yang mereka alami.
Kelemahan yang dialami oleh pengurus FPA disebabkan oleh kurangnya kompetensi mereka dalam menyelenggarakan kegiatan kelompok belajar. Selain itu mereka juga mengalami kesulitan dalam mengakses sumber. Kesulitan ini terjadi karena terbatasnya pengetahuan mereka tentang sumber yang dapat diakses, dan kurangnya keterampilan mereka dalam mengakses sumber-sumber yang dibutuhkan. Kelemahan inilah yang kemudian melatarbelakangi perlunya pemberdayaan terhadap lembaga FPA.

Pemberdayaan FPA dilakukan dalam bentuk mengganti kepengurusan dengan melibatkan anggota masyarakat yang memiliki potensi dalam kegiatan pendidikan. Penempatan orang-orang yang memiliki kompetensi dalam pelaksanaan kegiatan kelompok belajar ini tidak hanya memicu dukungan dari masyarakat setempat, tetapi juga mendorong adanya dukungan dari dunia usaha dalam pelaksanaan kegiatan. Hal ini berdampak pada kemampuan FPA untuk menjalankan fungsinya sehingga kegiatan kelompok belajar dapat dilaksanakan. Keberhasilan pemberdayaan lembaga FPA tidak serta merta berdampak pada menurunnya jumlah pekerja anak. Namun demikian, setidaknya FPA sudah berhasil memulai kegiatan untuk memenuhi kebutuhan pendidikan bagi pekerja anak. Keberhasilan FPA menjalankan kegiatannya menunjukkan adanya kemampuan masyarakat Kelurahan Cibeureum untuk menangani masalah pekerja 
anak di wilayahnya. Kegiatan ini perlu mendapatkan dukungan dari Pemerintah Kota Cimahi untuk kesinambungan kegiatan, sehingga tujuan mengembalikan pekerja anak ke dunia pendidikan akan dapat tercapai.

\section{Pemberdayaaan Bagi Pekerja Anak}

Pembahasan mengenai pemberdayaan mencakup dua hal utama yaitu adanya kelompok yang berdaya dan yang tidak berdaya. Pengertian pemberdayaan disampaikan oleh Paul (1987) dalam Prijono (1996:63) menyebutkan bahwa:

"Pemberdayaan berarti pembagian kekuasaan yang adil sehingga meningkatkan kesadaran politis dan kekuasan kelompok yang lemah serta memperbesar pengaruh mereka terhadap proses dan hasil-hasil pembangunan".

Hassenfeld dalam Dubois dan Milley (1992:227) memberikan batasan pemberdayaan sebagai berikut : "Empowerment is process through which clien obtain resources -personal, organizational, community- that enable them to gain greater control over their environmental and to attain their aspirations". (Pemberdayaan merupakan suatu proses dimana klien memperoleh sumber-sumber, baik secara personal, organisasi, maupun kemasyarakatan, yang memungkinkan mereka untuk dapat melakukan kontrol yang lebih besar terhadap lingkungan dan menyampaikan aspirasinya).
Dari kedua pengertian tersebut dapat diketahui bahwa dalam konsep pemberdayaan tidak hanya berkaitan dengan pemberian daya atau kekuasaan, melainkan juga menyediakan sumber-sumber yang dapat diakses oleh klien dalam rangka menentukan masa depannya sendiri. Agar klien dapat menentukan masa depannya sendiri maka diperlukan upaya penumbuhan kesadaran dari mereka yang tidak berdaya. Penumbuhan kesadaran ini ditujukan agar mereka yang tidak berdaya sadar bahwa merekapun mempunyai kekuatan untuk menentukan keputusan dan tindakan yang akan mereka lakukan untuk masa depan yang mereka inginkan.

Hal ini sesuai dengan pendefinisian pemberdayaan yang disampaikan oleh Gutiérrez dalam DuBois (2005:25) yang menyatakan bahwa : "Empowerment is the process of increasing personal, interpersonal, or political power so that individuals, families, and communities can take action to improve their situations". Definisi tersebut menjelaskan bahwa pemberdayaan pada dasarnya merupakan proses peningkatan kekuatan personal, interpersonal dan politik sehingga individu, keluarga dan komunitas dapat bertindak untuk memperbaiki situasinya.

Pemberdayaan pada lembaga FPA dilakukan untuk meningkatkan keberdayaan pada dimensi interpersonal dan politik. Hal ini disebabkan pada kedua dimensi itu lembaga FPA kurang berdaya, sehingga tujuannya belum dapat dicapai. Peningkatan keberdayaan dimensi interpersonal dan politik dari lembaga FPA setelah melalui proses pemberdayaan, dapat membantu lembaga tersebut untuk 
mencapai tujuannya yaitu menyelenggarakan kegiatan kelompok belajar bagi pekerja anak.

\section{Perspektif yang Melandasi Penanganan Kesejahteraan Sosial Anak dalam Hal Pekerja Anak}

\section{Perspektif Ekologi}

Istilah ekologi merupakan istilah yang dipinjam dari ilmu biologi. Istilah tersebut menunjukkan adanya hubungan antara organisme dengan lingkungan fisik maupun biologis. Dalam konteks pekerjaan sosial istilah ekologi menggambarkan adanya hubungan antara manusia dengan lingkungan sosialnya. Hubungan tersebut berpengaruh terhadap kemampuan manusia untuk berfungsi sosial (Hilahan, Wilcox, Spearly,\& Campbell dalam DuBois, 2005).

Perspektif ekologi mendasari munculnya life model dalam pekerjaan sosial yang disampaikan oleh Germain\&Gitterman (DuBois, 2005). DuBois menyatakan bahwa: “...the transactions between people and their environments is the source of human needs and social problems. Human affect and are affected by their physical and social environments through a process of continuous, reciprocal adaptations". Pernyataan tersebut menjelaskan bahwa transaksi antara orang dengan lingkungannya merupakan penyebab masalah sosial sekaligus sebagai sumber untuk memenuhi kebutuhan manusia. Proses saling mempengaruhi antara manusia dengan lingkungan fisik dan sosialnya terjadi secara terus menerus dan timbal balik.

Permasalahan sosial dalam pandangan ekologi terjadi karena tiga hal yaitu : perubahan dalam kehidupan, tekanan lingkungan dan proses interpersonal. Berdasarkan perspektif ekologi praktek pekerjaan sosial bertujuan untuk mengoptimalkan kapasitas orang-orang dalam beradaptasi dengan lingkungannya. Tujuan tersebut dicapai melalui mengembangkan keterampilan pekerja anak untuk menjalankan fungsinya secara lebih efektif.

\section{Strengths Perspektif}

Sheafor dan Horesjsi (2003) menjelaskan bahwa perspektif kekuatan (strengths perspective) merupakan perspektif dalam pekerjaan sosial yang bertujuan untuk menjamin bahwa pekerja sosial memperhatikan kekuatan-kekuatan pekerja anak. Perspektif ini menekankan bahwa untuk menolong pekerja anak memecahkan masalahnya, dapat dilakukan dengan membangun kekuatan yang dimiliki oleh pekerja anak daripada mengurangi masalah yang dialaminya. Kekuatan dalam hal ini merupakan segala sesuatu yang penting yang dilakukan, dapat dilakukan atau ingin dilakukan oleh pekerja anak.

Intervensi dalam perspektif kekuatan mengutamakan pada pengubahan lingkungan pekerja anak terlebih dahulu, daripada melakukan perubahan pada pekerja anak itu 
sendiri. Prosesnya dilakukan melalui mobilisasi lingkungan dan sumber-sumber yang dimilikinya. Intervensi yang berlandaskan perspektif kekuatan erat hubungannya dengan pemberdayaan.

\section{SIMPULAN}

Pekerja anak merupakan permasalahan sosial yang dapat berdampak pada terganggunya proses tumbuh kembang anak. Pada masa anak idealnya seorang anak dapat terpenuhi kebutuhannya untuk dapat tumbuh dan berkembang secara optimal. Anak-anak yang menjadi pekerja anak cenderung mengalami hambatan dalam pemenuhan kebutuhannya, sehingga mereka tidak dapat tumbuh dan berkembang sesuai dengan tahapan perkembangannya.

Pekerja anak merupakan masalah sosial yang cukup menjadi perhatian dunia. Bentuk perhatian dunia tersebut antara lain diwujudkan melalui Konvensi Nomor 182 tentang Pelarangan dan Penghapusan dengan segera Bentuk-bentuk Pekerjaan Terburuk Anak. Protokol internasional ini mengharuskan setiap negara yang meratifikasi konvensi tersebut, untuk melakukan tindakan segera dalam penghapusan pekerja anak. Salah satu upaya yang disarankan untuk melakukan penghapusan pekerja anak adalah dengan mengembalikan pekerja anak ke dunia pendidikan.
Penghapusan pekerja anak di Indonesia diwujudkan melalui Keppres Nomor 12 tahun 2001 tentang pembentukan Komite Aksi Nasional. Komite ini bertugas menyusun Rencana Aksi Nasional untuk melakukan penghapusan segera terhadap pekerja anak. Penghapusan pekerja anak dalam pelaksanaannya melibatkan Pemerintah, dunia usaha, Perguruan Tinggi, LSM dan masyarakat.

Fenomena pekerja anak di Kelurahan Cibeureum merupakan permasalahan sosial yang hampir terabaikan. Mereka dapat dengan mudah ditemukan dalam kehidupan seharihari, namun tidak terdaftar dalam data penyandang masalah kesejahteraan sosial. Tidak tersedianya data yang memadai menyebabkan permasalahan sosial ini belum ditangani secara memadai. Kondisi tersebut menunjukkan bahwa keberadaan pekerja anak belum dianggap sebagai permasalahan sosial yang serius.

Sejalan dengan paradigma pembangunan partisipatif, maka penanganan permasalahan sosial yang ada di masyarakat dilakukan dengan mengoptimalkan potensi dan sumber yang ada di masyarakat. Potensi masyarakat dapat dimanfaatkan untuk menangani masalah pekerja anak antara lain : adanya lembaga pendidikan non formal, adanya anggota masyarakat yang memiliki latar belakang pendidikan keguruan, adanya dunia usaha yang memiliki kepedulian terhadap pendidikan anak dan kepedulian masyarakat untuk 
memenuhi kebutuhan pendidikan bagi pekerja anak.

Pemberdayaan tersebut dimaksudkan untuk meningkatkan kemampuan masyarakat dalam menangani masalah pekerja anak yang ada di wilyahnya. Pemberdayaan dilakukan dengan pertimbangan adanya potensi yang dimiliki masyarakat, namun karena kurangnya pengetahuan dan keterampilan dalam mengoptimalkannya sehingga mereka mengalami kesulitan dalam menangani masalah pekerja anak.

\section{DAFTAR PUSTAKA}

Bryant, C. dan White, G.,1987. M anajemen Pembangunan untuk Negara Berkembang, LP3ES, Jakarta

Dubois, Brenda and Milley. (1992). Social Work: an Empowering Profession. USA: Allyn and Bacon.

Gutiérrez, Lorraine M., Ruth Parsons and Enid Opal Cox. (1998). Empowerment in Social Work Practice : a Sourcebook. USA : F.E Peacock Publishers, Inc.

Hill, Malcolm and Kay Tisdall. (1997). Children and Society. London: Longman

Huraerah, Abu. (2006). Kekerasan Terhadap Anak. Bandung : Penerbit Nuansa

Hurlock, Elizabeth B. (1993). Psikologi Perkembangan: Suatu pendekatan Sepanjang Rentang Kehidupan. (edisi ke 5) .Jakarta: Erlangga

Ife, Jim. (2002). Community Development : community-based alternatives in an age of globalisation. Australia : Longman
Moleong, Lexy J. (2000). Metodologi Penelitian Kualitatif. Bandung : PT. Remaja Rosdakarya.

Netting, F. Ellen. (1993). Social Work Macro Practice. New York: Longman (2004). Social Work Macro Practice. New York : Longman.

Papalia, Diane E.et.al. (2001). Human Development $\left(8^{\text {th }}\right.$ ed). New York: McGraw-Hill Companies

Prijono, Onny S. dan A.M.W. Pranarka. (1996). Pemberdayaan : Konsep, Kebijakan dan Implementasi. Jakarta : CSIS

Queralt, Magally. (1996). The Social Environment And Human Behavior: A Diversity Perspective. USA: Allyn \& Bacon

Sheafor, Bradford W., Charles R. Horesjsi. (2003). Techniques and Guidelines for Social Work Practice. United States: Pearson Education, Inc.

Soekanto, Soerjono. (1990). Sosiologi Suatu Pengantar (Edisi Keempat). Jakarta: RajaGrafindo Persada

Sugiyono. (2007). Metode Penelitian Kuantitatif Kualitatif dan $R \& D$. Bandung : Penerbit Alfabeta.

Suharto, Edi. (1997). Pembangunan, Kebijakan Sosial dan Pekerjaan Sosial, Spektrum Pemikiran. Bandung: LSP-STKS. (2005). Membangun Masyarakat Memberdayakan Rakyat: Kajian Strategis Pembangunan Kesejahteraan Sosial dan Pekrjaan Sosial. Bandung: PT. Refika Aditama.

Wadsworth, Yoland. (1993). Everyday Evaluation on the Run. Melbourne: Teh Action Research Issues Association (Incorporated).

Yusuf, Syamsu. (2004). Psikologi Perkembangan Anak dan Remaja. Bandung : Rosda Karya 
Agustiar, Dwi Riyanto. (2007). Jumlah Pekerja Anak di Indonesia Masih Tinggi.

http://www.tempointeraktif.com/hg/n asional/2007/04/30/brk.2007043099130.id.html

ILO-IPEC, APEC, (2002), Buku I Pekerja Anak, Hak-hak Anak, Dan Pendidikan : Jakarta

Undang-Undang Nomor 4 tahun 1979 tentang Kesejahteraan Anak

Undang-undang Nomor 1 tahun 2000 tentang Pengesahan Konvensi ILO Nomor 182 mengenai Pelarangan dan Tindakan Segera Penghapusan
Bentuk-bentuk Pekerjaan Terburuk Untuk Anak.

Undang-undang Nomor 23 tahun 2002 tentang Perlindungan Anak

Undang-undang Nomor 13 tahun 2003 tentang Ketenagakerjaan.

Keppres RI Nomor 12 tahun 2001 tentang Pembentukan Komite Aksi Nasional Penghapusan Bentuk-bentuk Pekerjaan Terburuk Untuk Anak.

Keppres RI Nomor 59 tahun 2002 tentang Rencana Aksi Nasional Penghapusan Bentuk-bentuk Pekerjaan Terburuk Untuk Anak. 